\title{
PETROGRAFIE A MINERALOGIE KRUPNÍKOVÉHO TĚLESA NA LOKALITĚ ZADNÍ HUTISKO U VERNÍŘOVIC (HRUBÝ JESENÍK)
}

\author{
Petrography and mineralogy of a soapstone body at the locality "Zadní Hutisko" near \\ Vernířovice (Hrubý Jeseník Mts.)
}

\author{
Jiří Zimák, Zuzana Juránková \\ Katedra geologie PřF UP, tř. 17. listopadu 12, 77146 Olomouc
}

Key words: Silesicum, Sobotín Massif, soapstone, talc schist, tremolite schist, chlorite schist, epidote-chlorite granofels

\begin{abstract}
The paper deals with mineralogy and petrology of a soapstone body at the locality Zadni Hutisko near Vernírovice in the Hrubý Jeseník Mts. (NE part of the Bohemian Massif). The soapstone body is located in the northern spur of the Sobotin Massif composed dominately of amphibolites. The soapstone body shows a very distinct symmetrical internal zonation. Four main types of rocks can be distinguished in the direction from the centre to the edge of the body: i) soapstone (talc + dolomite); ii) talc schist; iii) tremolite schist; iv) chlorite schist. Common accessory minerals of the rocks are apatite and magnetite. Formation of the studied soapstone body may have been caused by metasomatic alteration of peridotite (serpentinite). Epidote-chlorite granofels with a variable content of amphibole (magnesiohornblende or tschermakite) and with a high content of opaque ore minerals (magnetite, hematite, and also ilmenite) was found at the contact of the soapstone body with amphibolite. Epidote-chlorite granofels has been formed by alteration of amphibolite.
\end{abstract}

Úvod

Součástí sobotínského masivu jsou drobná krupníková tělesa. Dvě největší a současně nejznámější $\mathrm{z}$ nich (nejen $\mathrm{v}$ sileziku, ale i v rámci celé ČR) mají status přírodní památky. Jde o PP Smrčina u Sobotína a PP Zadní Hutisko u Vernírovic (obě PP byly vyhlášeny v r. 1982 - Šafár et al. 2003). V tomto článku je petrograficky a mineralogicky zhodnoceno těleso vystupující na lokalitě Zadní Hutisko.

\section{Stručná charakteristika sobotínského masivu}

Sobotínský masiv (nebo též sobotínský amfibolitový masiv) je součástí silezika. Jde o relativně velké těleso složené $\mathrm{z}$ metamorfovaných bazických, intermediárních i ultrabazických hornin, podrobně petrograficky zhodnocených Kretschmerem (1911), na nějž později navázali např. Pouba (1969, 1971), Fiala et al. (1980) a Souček (1981). Zjednodušená geologická mapa sobotínského masivu je uvedena na obrázku 1. Již Kretschmer (1911) považuje amfibolity a amfibolické ruly sobotínského masivu za metamorfovaná gabra a diority. Převládajícím horninovým typem jsou drobně až středně zrnité amfibolity, někdy všesměrně zrnité, jindy výrazně páskované (hlavně $\mathrm{v}$ př́ípadě variet $s$ vyšším obsahem živce). Zejména při Z. okraji masivu se vyskytují

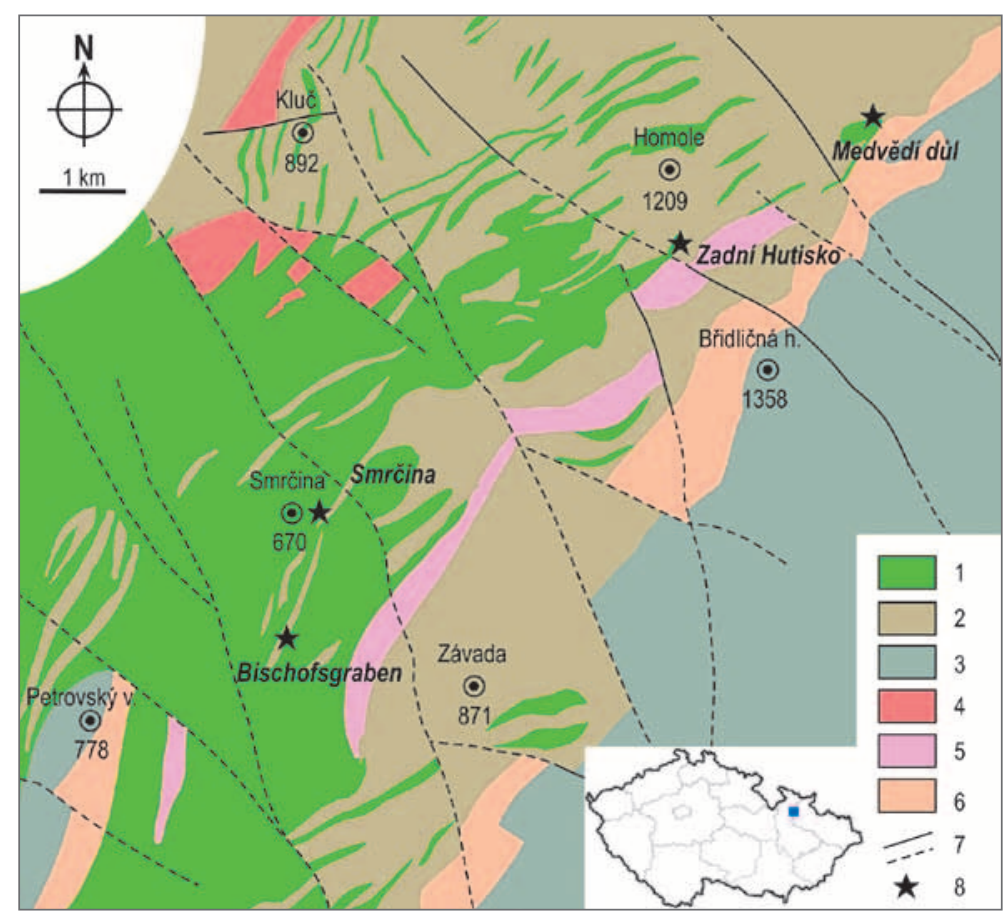

Obr. 1: Zjednodušená geologická mapa sobotínského masivu (podle Opletala et al. 1996 a 1997, upraveno autory). 1 - amfibolity a amfibolické ruly sobotínského masivu; 2 - desenská rula, místy zpětně metamorfovaná; 3 - fylity a kvarcity vrbenské skupiny; 4 - granitoidy intruze Rudné hory; 5 - blastomylonity; 6 - metagranitoidy; 7 - zlom ověřený a zlom předpokládaný; 8 - krupníková tělesa zmiňovaná v článku.

Fig. 1: Simplified geological map of the Sobotín Massif (according to Opletal et al. 1996 and 1997, modified). 1 - amphibolites and amphibole gneisses of the Sobotín Massif; 2 - biotite gneiss (so-called Desná gneiss), locally retrograded; 3 - phyllites and quartzites of the Vrbno Group; 4 - granitoids of the Rudná Mt. Intrusion; 5 - blastomylonites; 6 - metagranitoids; 7 - verified faults and presumed faults; 8 - soapstone bodies mentioned in the article. 
hrubozrnné amfibolity (tzv. gabroamfibolity) - viz např. Koverdynský (1993). Součástí sobotínského masivu jsou i amfibolické a biotit-amfibolické ruly (metadiority), metahornblendity, serpentinity, chloritické a aktinolitické břidlice a též krupníková tělesa. Tato tělesa mají víceméně čočkovitý tvar a vždy výraznou koncentricky zonální stavbu. Jejich centrální část je tvořena krupníkem a mastkovou břidlicí, směrem k okraji přecházející do zóny aktinolitické (př́íp. tremolitické) břidlice, vnější zóna má charakter chloritické břidlice (např. Kretschmer 1911).

Sobotínský masiv je všeobecně považován za intruzívní těleso devonského stáří (stř̌ední až svrchní devon - viz např. Koverdynský 1993), podle některých autorů může být zařazení sobotínského masivu do devonu poněkud sporné, intruze proběhla v několika etapách (jak uvádí např. Pouba et al. 1962). Amfibolity a metahornblendity vykazují tholeitický trend, jejich geotektonická pozice je nejasná (Souček 1981; Přichystal a Novotný 1999). Horniny sobotínského masivu byly postiženy variskou metamorfózou za podmínek amfibolitové facie, Košuličová a Štípská (2007) a Schulmann et al. (2014) považují variskou metamorfózu silezika za barrovianskou, v prostoru sobotínského masivu odpovídající staurolitové zóně.

\section{Charakteristika lokality a historie výzkumu}

Lom označovaný jako Zadní Hutisko (dříve ozn. Hintere Hüttellehne, prŕípadně jen Hüttellehne) je situován v poměrně strmém svahu nad pravým břehem Merty, zhruba $3,5 \mathrm{~km}$ sv. od kostela ve Vernírovicích a $1 \mathrm{~km}$ j. od kóty Homole, dř. Hutisko (1 209 m). Kolem lomu prochází lesní silnice („Hrázová cesta“), vedoucí z údolí Merty do sedla Branka pod Jestř́ábím vrchem. Současný stav lokality je zřejmý z obrázku 2, prostor lomu je udržován odstraňováním náletových dřevin.

Zadní Hutisko je jedním ze šesti krupníkových těles $\mathrm{v}$ prostoru sobotínského masivu, otevřených v 18. a 19. století lomy. V nich těžený krupník byl využíván například ke zhotovování bazické vyzdívky pro železárny (v Sobotíně i jinde) a na kamenické práce (žlaby, schody,

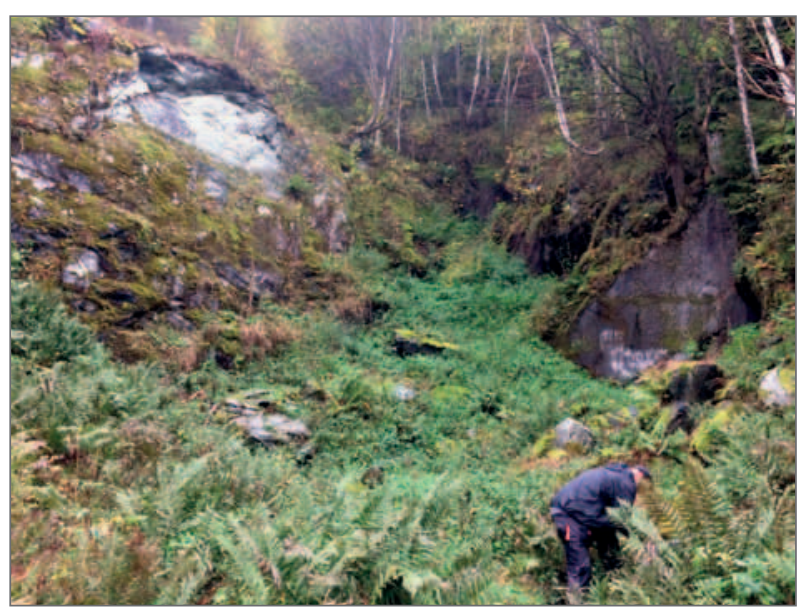

Obr. 2: Lokalita Zadní Hutisko - současný stav (ř́ijen 2017). Autor Z. Juránková.

Fig. 2: Locality Zadní Hutisko - current state (October 2017). Author Z. Juránková. dveřní a okenní rámy, sloupky, náhrobky) - Kretschmer (1911), podrobně Gába (1989).

Podle Kretschmera (1911) jsou na lokalitě Zadní Hutisko tři vedle sebe těsně ležící čočkovitá krupníková tělesa s charakteristickou zonální stavbou. Centrální část tvoří krupník, jenž je lemován mastkovou břidlicí, dále směrem k periferii následuje aktinolitická břidlice (resp. aktinolitovec), na okraji tělesa je chloritová břidlice, která se stýká s okolním amfibolitem; mocnost čočky s popsanou stavbou činí 35 m (Kretschmer 1911). Zimák a Novotný (2002) vyjadřují zonální stavbu tělesa na Zadním Hutisku posloupností těchto horninových typů (od centra k okraji): krupník - mastková břidlice - tremolitická břidlice (resp. skalina) - aktinolitická břidlice (resp. skalina) - chloritická břidlice. Obdobnou stavbu mají i další krupníková tělesa na Sobotínsku. Ve studii Fialy et al. (1980) lze najít údaje o chemismu hornin ze Zadního Hutiska a některých jejich minerálů, avšak bez podrobnější petrografické či mineralogické charakteristiky (studie je zaměřena na geochemii ultrabazik sobotínského masivu). Nutno poznamenat, že Fiala et al. (1980) zmiňují ze Zadního Hutiska i „chlorit-amfibol-epidotovou horninu“.

Jelínek a Souček (1981) tvrdí, že v rámci každého tělesa lze sledovat od jádra k okraji tyto zóny: serpentinit - krupník - mastková břidlice - aktinolitická břidlice (aktinolitovec) - chloritická břidlice.

Zimák a Novotný (2002) uvádí první komplexní petrografické a mineralogické hodnocení krupníkového tělesa na lokalitě Zadní Hutisko, založené jak na studiu výbrusů pomocí polarizačního mikroskopu, tak na sledování chemického složení hornin (analýzy na mokré cestě) a zejména hlavních horninotvorných minerálů (mikrosondové analýzy v modu EDX).

Krupníkový lom na Zadním Hutisku patří mezi klasické mineralogické lokality na území Jeseníků. Informace o zajímavých nálezech minerálů na této lokalitě uvádí např. Burkart (1953), Kruta et al. (1967), Nepejchal (2000), Zimák a Novotný (2002), Novotný (1998, 2003).

\section{Metodika}

Většina studovaných vzorků byla odebrána prvním $\mathrm{z}$ autorů již v 70. letech 20 . století na všech třech etážích lomu na Zadním Hutisku a také $\mathrm{z}$ deponie těžebního odpadu při vstupní ćásti lomu, odkryté při rekonstrukci Hrázové cesty. Terénní práce na lokalitě byly ukončeny $\mathrm{v}$ roce 2017.

Základem mineralogicko-petrografického hodnocení vybraných horninových vzorků je mikroskopické studium výbrusů a nábrusů v procházejícím a odraženém světle za použití standardního polarizačního mikroskopu. Struktura hornin byla posuzována i na základě BSE obrazu.

Údaje o chemismu 49 vzorků reprezentujících jednotlivé zóny krupníkového tělesa a horniny v jeho bezprostředním okolí (tab. 1) byly získány pomocí XRF analyzátoru DELTA-PREMIUM v laboratořích firmy URGA, s.r.o. se sídlem v Olomouci (použitou metodiku popisuje Zimák et al. 2016). Obsahy uranu a thoria 
Tab. 1: Chemismus hornin krupníkového tělesa, chlorit-epidotové skaliny a okolního amfibolitu, XRF analýza (celkové železo uvedeno jako $\mathrm{FeO}, \mathrm{n}$ = počet vzorků, $\mathrm{x}=$ průměr).

Tab. 1: Chemical composition of rocks of the soapstone body, chlorite-epidote granofels and amphibolite, XRF analysis (total iron is presented as $\mathrm{FeO}, \mathrm{n}=$ number of samples, $\mathrm{x}=$ average).

\begin{tabular}{|c|c|c|c|c|c|c|c|c|c|}
\hline & \multicolumn{3}{|c|}{$\begin{array}{c}\text { krupník } \\
(\mathrm{n}=9)\end{array}$} & \multicolumn{3}{|c|}{$\begin{array}{c}\text { mastková břidlice } \\
(\mathrm{n}=11)\end{array}$} & \multicolumn{3}{|c|}{$\begin{array}{l}\text { tremolitická břidlice } \\
\qquad(\mathrm{n}=6)\end{array}$} \\
\hline & min. & $\max$. & $\mathrm{x}$ & min. & $\max$. & $\mathrm{x}$ & $\min$. & $\max$. & $\mathrm{x}$ \\
\hline $\mathrm{SiO}_{2}(\mathrm{hm} . \%)$ & 42,1 & 55,7 & 49,8 & 56,0 & 68,6 & 62,1 & 45,2 & 54,1 & 49,0 \\
\hline $\mathrm{TiO}_{2}(\mathrm{hm} . \%)$ & $<0,07$ & $<0,07$ & - & $<0,07$ & $<0,07$ & - & $<0,07$ & 0,16 & 0,08 \\
\hline $\mathrm{Al}_{2} \mathrm{O}_{3}(\mathrm{hm} . \%)$ & 1,2 & 3,2 & 1,9 & 0,6 & 2,1 & 1,4 & 2,5 & 3,9 & 3,3 \\
\hline $\mathrm{Cr}_{2} \mathrm{O}_{3}(\mathrm{hm} . \%)$ & 0,10 & 0,26 & 0,18 & 0,11 & 0,60 & 0,24 & 0,11 & 0,31 & 0,17 \\
\hline MgO (hm. \%) & 22,6 & 30,7 & 27,8 & 25,1 & 32,8 & 29,8 & 19,0 & 25,9 & 23,1 \\
\hline $\mathrm{FeO}(\mathrm{hm} . \%)$ & 4,5 & 7,1 & 5,7 & 3,6 & 6,8 & 5,7 & 4,4 & 5,7 & 5,2 \\
\hline $\mathrm{CaO}$ (hm. \%) & 2,0 & 15,8 & 5,1 & 0,7 & 2,7 & 1,3 & 10,5 & 11,7 & 11,2 \\
\hline $\mathrm{MnO}$ (hm. \%) & 0,06 & 0,20 & 0,12 & 0,02 & 0,08 & 0,05 & 0,14 & 0,24 & 0,18 \\
\hline Sr (ppm) & 20 & 160 & 62 & $<10$ & 62 & 19 & 16 & 55 & 29 \\
\hline $\mathrm{Zr}(\mathrm{ppm})$ & $<3$ & 10 & 6 & 7 & 13 & 8 & $<3$ & 9 & 6 \\
\hline Co (ppm) & 30 & 87 & 60 & 52 & 92 & 72 & $<10$ & 41 & 26 \\
\hline Ni (ppm) & 1789 & 2864 & 2362 & 1544 & 3193 & 2462 & 1051 & 1607 & 1315 \\
\hline $\mathrm{Cu}(\mathrm{ppm})$ & $<10$ & 202 & 33 & $<10$ & 109 & $<10$ & $<10$ & $<10$ & - \\
\hline $\mathrm{Zn}$ (ppm) & 24 & 75 & 42 & 45 & 115 & 69 & 39 & 58 & 47 \\
\hline
\end{tabular}

\begin{tabular}{|l|c|c|c|c|c|c|c|c|c|}
\hline & \multicolumn{3}{|c|}{$\begin{array}{c}\text { chloritická břidlice } \\
\text { (n= 9) }\end{array}$} & \multicolumn{2}{c|}{ epidot-chloritová skalina } & \multicolumn{3}{c|}{ amfibolit } \\
(n= 9)
\end{tabular}

v 42 horninových vzorcích byly stanoveny laboratorním gamaspektrometrem SG - 1000 LAB na PřF UP Olomouc.

Chemické složení vybraných minerálů bylo studováno metodou EDX na prrístroji CamScan s připojeným EDX analyzátorem Link AN 10000 (30 bodových analýz, analytik V. Vávra, PřF MU Brno) a metodou WDX pomocí elektronového mikroanalyzátoru Cameca SX100 (49 bodových analýz, analytici P. Gadas, R. Škoda a J. Haifler, PřF MU Brno). Výsledky reprezentativních WDX analýz amfibolů, chloritů, mastku, epidotu a flogopitu z hornin krupníkového tělesa a epidot-chloritové skaliny z kontaktu krupníkového tělesa s amfibolitem jsou uvedeny v tabulce 2 a 3 . V pŕípadě amfibolů byly hodnoty apfu vypočteny na bázi 23 atomů kyslíku, poměr mezi $\mathrm{Fe}^{3+} \mathrm{a} \mathrm{Fe}^{2+}$ byl kalkulován na základě $\mathrm{T}+\mathrm{C}=13$. U dalších silikátů v tabulce 2 a 3 je celkové železo uváděno bud' jako $\mathrm{FeO}$ (chlorit, mastek, flogopit) nebo jako $\mathrm{Fe}_{2} \mathrm{O}_{3}$ (epidot). Kvantitativní poměr $\mathrm{Fe}^{3+} \mathrm{a} \mathrm{Fe}{ }^{2+} \mathrm{v}$ analyzovaných spinelidech byl vypočten na bázi 4 atomy kyslíku a $\Sigma \mathrm{R}^{3+}=2$. Chemismus ostatních minerálů je pouze stručně komentován v textu. Pokud jde o obsahy hlavních složek, neliší se výsledky
EDX analýz jednotlivých minerálů nijak zásadně od obsahů stanovených ve vlnově disperzním modu, a proto mohly být údaje založené na EDX analýzách začleněny do klasifikačních diagramů chloritů nebo amfibolů.

\section{Výsledky \\ Stavba krupníkového tělesa a chemismus hornin}

Na základě terénního výzkumu v lomu na Zadním Hutisku v kombinaci s výsledky mineralogicko-petrografického studia lze ve studovaném krupníkovém tělese rozlišit ve směru od centra k okraji čtyři hlavní horninové typy: krupník - mastková břidlice - tremolitická břidlice - chloritická břidlice. Nutno poznamenat, že do zóny s označením „tremolitická břidlice“ jsou zahrnuty jak horniny odpovídajícího složení s plošně paralelní texturou, tak i horniny s všesměrným uspořádáním prizmatických individuí amfibolu (tj. skaliny).

Petrografická povaha hornin krupníkového tělesa je dána kvantitativním poměrem čtyř hlavních minerálů: mastku (Tlc), klinoamfibolu odpovídajícího tremolitu až aktinolitu (dále jen Tr), chloritu (Chl) a také dolomitu 
Tab. 2: Reprezentativní WDX analýzy amfibolu, chloritu a mastku z hornin krupníkového tělesa (hornina: 1 až 5 a $8=$ chloritická břidlice, $6,7,9$ a 10 = aktinolitická břidlice).

Tab. 2: Representative WDX analyses of amphibole, chlorite and talc from rocks of the soapstone body (rock: 1 to 5 and $8=$ chlorite schist, 6, 7, 9 and $10=$ actinolite schist).

\begin{tabular}{|c|c|c|c|c|c|c|c|c|c|c|}
\hline \multirow[b]{2}{*}{ anal. č. } & \multicolumn{7}{|c|}{ amfibol } & \multicolumn{2}{|c|}{ chlorit } & \multirow{2}{*}{$\begin{array}{c}\text { mastek } \\
10\end{array}$} \\
\hline & 1 & 2 & 3 & 4 & 5 & 6 & 7 & 8 & 9 & \\
\hline $\mathrm{SiO}_{2}(\mathrm{hm} . \%)$ & 55,02 & 53,08 & 54,82 & 57,30 & 56,45 & 55,71 & 57,35 & 29,54 & 29,15 & 61,25 \\
\hline $\mathrm{TiO}_{2}$ (hm. \%) & 0,11 & 0,15 & 0,10 & 0,02 & 0,04 & 0,05 & 0,01 & 0,05 & 0,02 & 0,02 \\
\hline $\mathrm{P}_{2} \mathrm{O}_{5}(\mathrm{hm} . \%)$ & nest. & nest. & nest. & 0,04 & 0,00 & 0,01 & 0,02 & nest. & nest. & nest. \\
\hline $\mathrm{Al}_{2} \mathrm{O}_{3}(\mathrm{hm} . \%)$ & 2,18 & 4,06 & 2,48 & 0,93 & 0,99 & 2,15 & 0,28 & 18,54 & 19,2 & 0,13 \\
\hline $\mathrm{Cr}_{2} \mathrm{O}_{3}(\mathrm{hm} . \%)$ & 0,10 & 0,01 & 0,12 & 0,08 & 0,36 & 0,17 & 0,05 & 0,45 & 0,41 & 0,02 \\
\hline $\mathrm{Sc}_{2} \mathrm{O}_{3}(\mathrm{hm} . \%)$ & nest. & nest. & nest. & 0,00 & 0,00 & 0,00 & 0,01 & nest. & nest. & nest. \\
\hline $\mathrm{V}_{2} \mathrm{O}_{3}(\mathrm{hm} . \%)$ & nest. & nest. & nest. & 0,02 & 0,05 & 0,03 & 0,00 & 0,00 & 0,01 & 0,00 \\
\hline $\mathrm{Fe}_{2} \mathrm{O}_{3}(\mathrm{hm} . \%)$ & 1,64 & 3,93 & 3,66 & 0,03 & 0,67 & 1,41 & 0,00 & - & - & - \\
\hline $\mathrm{FeO}(\mathrm{hm} . \%)$ & 4,43 & 3,79 & 1,90 & 5,06 & 4,58 & 1,82 & 4,50 & 9,88 & 10,26 & 4,60 \\
\hline $\mathrm{MgO}$ (hm. \%) & 19,94 & 19,08 & 20,49 & 20,39 & 20,47 & 21,91 & 21,12 & 26,65 & 25,42 & 25,67 \\
\hline $\mathrm{MnO}$ (hm. \%) & 0,15 & 0,17 & 0,26 & 0,29 & 0,23 & 0,11 & 0,18 & 0,09 & 0,13 & 0,02 \\
\hline $\mathrm{NiO}$ (hm. \%) & nest. & nest. & nest. & 0,14 & 0,17 & 0,13 & 0,18 & 0,21 & 0,19 & 0,62 \\
\hline $\mathrm{CaO}$ (hm. \%) & 12,99 & 12,79 & 12,55 & 12,72 & 12,84 & 13,14 & 13,19 & 0,02 & 0,02 & 0,01 \\
\hline $\mathrm{ZnO}$ (hm. \%) & nest. & nest. & nest. & 0,01 & 0,00 & 0,03 & 0,00 & 0,05 & 0,00 & 0,00 \\
\hline SrO (hm. \%) & nest. & nest. & nest. & nest. & nest. & nest. & nest. & 0,00 & 0,00 & 0,00 \\
\hline $\mathrm{BaO}$ (hm. \%) & nest. & nest. & nest. & nest. & nest. & nest. & nest. & 0,00 & 0,00 & 0,00 \\
\hline $\mathrm{K}_{2} \mathrm{O}(\mathrm{hm} . \%)$ & 0,03 & 0,04 & 0,01 & 0,01 & 0,06 & 0,06 & 0,03 & 0,00 & 0,01 & 0,03 \\
\hline $\mathrm{Na}_{2} \mathrm{O}$ (hm. \%) & 0,21 & 0,53 & 0,33 & 0,20 & 0,19 & 0,35 & 0,13 & 0,00 & 0,00 & 0,04 \\
\hline F (hm. \%) & nest. & nest. & nest. & 0,10 & 0,12 & 0,09 & 0,09 & 0,02 & 0,00 & 0,06 \\
\hline $\mathrm{Cl}$ (hm. \%) & nest. & nest. & nest. & 0,00 & 0,01 & 0,01 & 0,00 & 0,00 & 0,00 & 0,00 \\
\hline $\mathrm{O}=\mathrm{F}(\mathrm{hm} . \%)$ & 0,00 & 0,00 & 0,00 & $-0,04$ & $-0,05$ & $-0,04$ & $-0,04$ & $-0,01$ & 0,00 & $-0,03$ \\
\hline $\mathrm{O}=\mathrm{Cl}(\mathrm{hm} . \%)$ & 0,00 & 0,00 & 0,00 & 0,00 & 0,00 & 0,00 & 0,00 & 0,00 & 0,00 & 0,00 \\
\hline suma (hm. \%) & 96,79 & 97,63 & 96,72 & 97,29 & 97,17 & 97,14 & 97,10 & 85,49 & 84,82 & 92,44 \\
\hline $\mathbf{S i}^{4+}$ & 7,73 & 7,44 & 7,66 & 7,96 & 7,88 & 7,71 & 7,98 & 2,94 & 2,93 & 4,07 \\
\hline $\mathrm{Ti}^{4+}$ & 0,01 & 0,02 & 0,01 & 0,00 & 0,00 & 0,01 & 0,00 & 0,00 & 0,00 & 0,00 \\
\hline $\mathbf{P}^{5+}$ & - & - & - & 0,01 & 0,00 & 0,00 & 0,00 & - & - & - \\
\hline $\mathbf{A l}^{3+}$ & 0,36 & 0,67 & 0,41 & 0,15 & 0,16 & 0,35 & 0,05 & 2,17 & 2,27 & 0,01 \\
\hline $\mathrm{Cr}^{3+}$ & 0,01 & 0,00 & 0,01 & 0,01 & 0,04 & 0,02 & 0,01 & 0,04 & 0,03 & 0,00 \\
\hline $\mathbf{V}^{3+}$ & - & - & - & 0,00 & 0,01 & 0,00 & 0,00 & 0,00 & 0,00 & 0,00 \\
\hline $\mathrm{Fe}^{3+}$ & 0,17 & 0,42 & 0,39 & 0,00 & 0,07 & 0,15 & 0,00 & 0,00 & 0,00 & 0,00 \\
\hline $\mathrm{Fe}^{2+}$ & 0,52 & 0,45 & 0,22 & 0,59 & 0,53 & 0,21 & 0,52 & 0,82 & 0,86 & 0,26 \\
\hline $\mathrm{Mg}^{2+}$ & 4,18 & 3,99 & 4,27 & 4,23 & 4,26 & 4,52 & 4,38 & 3,95 & 3,80 & 2,54 \\
\hline $\mathrm{Mn}^{2+}$ & 0,02 & 0,02 & 0,03 & 0,03 & 0,03 & 0,01 & 0,02 & 0,01 & 0,01 & 0,00 \\
\hline $\mathrm{Ni}^{2+}$ & - & - & - & 0,02 & 0,02 & 0,01 & 0,02 & 0,02 & 0,02 & 0,03 \\
\hline $\mathrm{Ca}^{2+}$ & 1,96 & 1,92 & 1,88 & 1,89 & 1,92 & 1,95 & 1,97 & 0,00 & 0,00 & 0,00 \\
\hline $\mathbf{K}^{+}$ & 0,01 & 0,01 & 0,00 & 0,00 & 0,01 & 0,01 & 0,01 & 0,00 & 0,00 & 0,00 \\
\hline $\mathrm{Na}^{+}$ & 0,06 & 0,14 & 0,09 & 0,05 & 0,05 & 0,09 & 0,04 & 0,00 & 0,00 & 0,01 \\
\hline $\mathrm{F}^{-}$ & - & - & - & 0,04 & 0,05 & 0,04 & 0,04 & 0,01 & 0,00 & 0,01 \\
\hline $\mathbf{O}^{2-}$ & 23,00 & 23,00 & 23,00 & 22,96 & 22,95 & 22,96 & 22,96 & 13,99 & 14,00 & 10,99 \\
\hline
\end{tabular}

(Dol). Kromě anchimonominerální Tlc-břidlice, Tr-břidlice (a skaliny) a Chl-břidlice jsou zde př́itomny přechodné horninové typy s různým poměrem Tlc/Tr a také Tr/Chl. Typický krupník je tvořen asociací Tlc + Dol, ubýváním Dol krupník přechází do Tlc-břidlice. Rozdíly v chemickém složení Tlc, Tr, Chl a Dol jsou podstatné, a proto existují i zásadní rozdíly v chemismu hlavních typů hornin. Výsledky XRF analýz hornin jsou sumarizovány v tabulce 1, obsahy hlavních složek jsou vyjádřeny formou Harkerova diagramu na obrázku 3. V souboru analyzovaných vzorků jsou zastoupeny vedle hornin s výraznou dominancí jednoho ze tří uvedených silikátů i horniny přechodného nerostného složení. To se projevuje značným rozpětím obsahů jednotlivých složek $\mathrm{v}$ rámci každého horninového typu. $\mathrm{Z}$ dat $\mathrm{v}$ tabulce 1 a zejména z obrázku 3 je zřejmý výrazný růst obsahu $\mathrm{SiO}_{2}$ ve směru od okraje do centra krupníkového tělesa, přesněji od Chl-břidlice přes Tr-břidlici po Tlc-břidlici. Obsah $\mathrm{SiO}_{2}$ v krupníku je výrazně nižší ve srovnání $\mathrm{v}$ Tlc-břidlicí, a to zejména vlivem značného množství Dol v krupníku. Druhou hlavní složkou hornin je MgO, jehož obsah je nejvyšší v horninách s dominancí mastku. Zvýšené obsahy $\mathrm{Al}_{2} \mathrm{O}_{3}$ a také $\mathrm{FeO}$ vykazují Chl-břidlice. Relativně vysoké obsahy $\mathrm{CaO}$ byly vždy zjištěny v Tr-břidlicích, naopak velmi nízké obsahy $\mathrm{CaO}$ jsou typické pro Tlc-břidlice a Chl-břidlice bez podstatného zastoupení amfibolu. Obsahy všech pěti hlavních oxidů stanovených XRF analýzou jsou zcela v souladu s nerostným složením horninových typů. Ze stopových prvků byly ve všech horninách krupníkového tělesa zjištěny relativně vysoké 
Tab. 3: Reprezentativní WDX analýzy epidotu, amfibolu, chloritu a flogopitu z epidotové-chloritové skaliny.

Tab. 3: Representative WDX analyses of epidote, amphibole, chlorite and phlogopite from epidote-chlorite granofels.

\begin{tabular}{|c|c|c|c|c|c|c|c|c|c|c|}
\hline & \multicolumn{3}{|c|}{ epidot } & \multicolumn{3}{|c|}{ amfibol } & \multicolumn{3}{|c|}{ chlorit } & flogopit \\
\hline anal. č. & 11 & 12 & 13 & 14 & 15 & 16 & 17 & 18 & 19 & 20 \\
\hline $\mathrm{SiO}_{2}(\mathrm{hm} . \%)$ & 37,39 & 37,75 & 37,37 & 49,12 & 45,56 & 43,9 & 27,92 & 26,89 & 26,96 & 37,05 \\
\hline $\mathrm{TiO}_{2}$ (hm. \%) & 0,07 & 0,07 & 0,17 & 0,21 & 0,37 & 0,38 & 0,08 & 0,10 & 0,08 & 1,44 \\
\hline $\mathrm{P}_{2} \mathrm{O}_{5}(\mathrm{hm} . \%)$ & 0,04 & 0,00 & 0,03 & 0,02 & 0,02 & 0,00 & nest. & nest. & nest. & nest. \\
\hline $\mathrm{Al}_{2} \mathrm{O}_{3}(\mathrm{hm} . \%)$ & 22,67 & 23,14 & 23,56 & 7,46 & 10,88 & 12,42 & 21,06 & 22,16 & 21,98 & 14,47 \\
\hline $\mathrm{Cr}_{2} \mathrm{O}_{3}(\mathrm{hm} . \%)$ & 0,04 & 0,00 & 0,01 & 0,01 & 0,01 & 0,01 & 0,02 & 0,00 & 0,00 & 0,00 \\
\hline $\mathrm{V}_{2} \mathrm{O}_{3}(\mathrm{hm} . \%)$ & 0,04 & 0,07 & 0,02 & 0,06 & 0,10 & 0,07 & 0,02 & 0,03 & 0,01 & nest. \\
\hline $\mathrm{Fe}_{2} \mathrm{O}_{3}(\mathrm{hm} . \%)$ & 13,59 & 13,86 & 12,72 & 6,31 & 6,67 & 6,37 & - & - & - & - \\
\hline $\mathrm{FeO}(\mathrm{hm} . \%)$ & - & - & - & 7,16 & 8,52 & 9,36 & 15,17 & 14,55 & 14,45 & 17,92 \\
\hline $\mathrm{MgO}$ (hm. \%) & 0,04 & 0,03 & 0,06 & 15,06 & 12,58 & 11,78 & 23,15 & 23,38 & 23,37 & 13,00 \\
\hline MnO (hm. \%) & 0,33 & 0,20 & 0,40 & 0,20 & 0,21 & 0,16 & 0,14 & 0,07 & 0,07 & 0,17 \\
\hline $\mathrm{NiO}$ (hm. \%) & 0,00 & 0,00 & 0,01 & 0,00 & 0,00 & 0,02 & 0,00 & 0,00 & 0,03 & nest. \\
\hline $\mathrm{CaO}$ (hm. \%) & 23,29 & 23,23 & 22,78 & 12,15 & 11,85 & 11,89 & 0,02 & 0,03 & 0,05 & 0,16 \\
\hline $\mathrm{ZnO}$ (hm. \%) & 0,00 & 0,01 & 0,07 & 0,00 & 0,00 & 0,05 & 0,02 & 0,02 & 0,01 & nest. \\
\hline SrO (hm. \%) & 0,25 & 0,17 & 0,31 & 0,00 & 0,00 & 0,00 & 0,00 & 0,00 & 0,00 & nest. \\
\hline $\mathrm{BaO}(\mathrm{hm} . \%)$ & nest. & nest. & nest. & nest. & nest. & nest. & 0,00 & 0,00 & 0,01 & nest. \\
\hline PbO (hm. \%) & nest. & nest. & nest. & nest. & nest. & nest. & 0,00 & 0,08 & 0,00 & nest. \\
\hline $\mathrm{K}_{2} \mathrm{O}(\mathrm{hm} . \%)$ & 0,00 & 0,01 & 0,00 & 0,11 & 0,19 & 0,28 & 0,00 & 0,01 & 0,01 & 8,81 \\
\hline $\mathrm{Na}_{2} \mathrm{O}$ (hm. \%) & 0,03 & 0,01 & 0,00 & 1,03 & 1,33 & 1,72 & 0,00 & 0,05 & 0,02 & 0,19 \\
\hline F (hm. \%) & 0,12 & 0,11 & 0,08 & 0,12 & 0,11 & 0,09 & 0,00 & 0,01 & 0,00 & nest. \\
\hline $\mathrm{Cl}$ (hm. \%) & 0,00 & 0,01 & 0,00 & 0,01 & 0,00 & 0,00 & 0,00 & 0,01 & 0,01 & nest. \\
\hline $\mathrm{O}=\mathrm{F}(\mathrm{hm} . \%)$ & $-0,05$ & $-0,05$ & $-0,03$ & $-0,05$ & $-0,05$ & $-0,04$ & 0,00 & 0,00 & 0,00 & 0,00 \\
\hline $\mathrm{O}=\mathrm{Cl}(\mathrm{hm} . \%)$ & 0,00 & 0,00 & 0,00 & 0,00 & 0,00 & 0,00 & 0,00 & 0,00 & 0,00 & 0,00 \\
\hline suma (hm. \%) & 97,85 & 98,62 & 97,56 & 98,98 & 98,35 & 98,46 & 87,60 & 87,38 & 87,06 & 93,21 \\
\hline $\mathrm{Si}^{4+}$ & 2,99 & 2,99 & 2,99 & 6,98 & 6,59 & 6,39 & 2,78 & 2,68 & 2,70 & 2,86 \\
\hline $\mathrm{Ti}^{4+}$ & 0,00 & 0,00 & 0,01 & 0,02 & 0,04 & 0,04 & 0,01 & 0,01 & 0,01 & 0,08 \\
\hline $\mathbf{A l}^{3+}$ & 2,14 & 2,16 & 2,22 & 1,25 & 1,86 & 2,13 & 2,47 & 2,61 & 2,59 & 1,32 \\
\hline $\mathbf{V}^{3+}$ & 0,00 & 0,00 & 0,00 & 0,01 & 0,01 & 0,01 & 0,00 & 0,00 & 0,00 & - \\
\hline $\mathrm{Fe}^{3+}$ & 0,82 & 0,83 & 0,77 & 0,67 & 0,73 & 0,70 & - & - & - & - \\
\hline $\mathrm{Fe}^{2+}$ & - & - & - & 0,85 & 1,03 & 1,14 & 1,26 & 1,21 & 1,21 & 1,16 \\
\hline $\mathbf{M g}^{2+}$ & 0,00 & 0,00 & 0,01 & 3,19 & 2,71 & 2,56 & 3,44 & 3,48 & 3,48 & 1,50 \\
\hline $\mathrm{Mn}^{2+}$ & 0,02 & 0,01 & 0,03 & 0,02 & 0,03 & 0,02 & 0,01 & 0,01 & 0,01 & 0,01 \\
\hline $\mathrm{Ca}^{2+}$ & 2,00 & 1,97 & 1,95 & 1,85 & 1,84 & 1,86 & 0,00 & 0,00 & 0,01 & 0,01 \\
\hline $\mathbf{Z n}^{2+}$ & 0,00 & 0,00 & 0,00 & 0,00 & 0,00 & 0,01 & 0,00 & 0,00 & 0,00 & 0,00 \\
\hline $\mathrm{Sr}^{2+}$ & 0,01 & 0,01 & 0,01 & 0,00 & 0,00 & 0,00 & 0,00 & 0,00 & 0,00 & - \\
\hline $\mathbf{K}^{+}$ & 0,00 & 0,00 & 0,00 & 0,02 & 0,04 & 0,05 & 0,00 & 0,00 & 0,00 & 0,87 \\
\hline $\mathrm{Na}^{+}$ & 0,00 & 0,00 & 0,00 & 0,28 & 0,37 & 0,49 & 0,00 & 0,01 & 0,00 & 0,03 \\
\hline $\mathrm{F}^{-}$ & 0,03 & 0,03 & 0,02 & 0,05 & 0,05 & 0,04 & 0,00 & 0,00 & 0,00 & - \\
\hline $\mathrm{O}^{2-}$ & 12,47 & 12,47 & 12,48 & 22,95 & 22,95 & 22,96 & 14,00 & 14,00 & 14,00 & 11,00 \\
\hline
\end{tabular}

obsahy niklu, v mastkové břidlici dosahující až 0,32 hm. \% $\mathrm{Ni}$ (tab. 1).

\section{Mineralogicko-petrografická charakteristika hornin krupníkového tělesa}

Krupník je tvořen hlavně jemně šupinkovitým šedobílým mastkem a porfyroblasty dolomitu, jejichž velikost je obvykle 5 až $10 \mathrm{~mm}$. Dolomit je šedobílý nebo jemně nažloutlý, v partiích postižených zvětráváním bývá okrově zbarven, částečně nebo totálně nahrazen limonitem, příp. po něm v hornině zůstávají prázdné kaverny. Ve variabilním množství se na složení krupníku podílí chlorit, tvořící černozelené šupinky nebo lupínky, jejichž velikost může dosahovat až kolem $10 \mathrm{~mm}$. Ojedinělou součástí jsou stébla šedozeleného až zeleného amfibolu (ve výbrusech většinou bezbarvého, bez pozorovatelného pleochroismu). Výše zmíněné hrubě lupenité agregáty nazelenalého mastku s velkými krystaly dolomitu bývají př́tomny v relativně úzké zóně, v níž krupník přechází do Tlc-břidlice.

Mastková břidlice je světle šedá, jemně šupinkovitá hornina s výraznou plošně paralelní texturou. Bývají v ní přítomny porfyroblasty chloritu - až $3 \mathrm{~mm}$ velké šedohnědé tabulky s dokonale vyvinutými bazálními plochami, často mírně zvlněné, probíhající kose k hlavnímu foliačnímu systému, někdy jsou součástí horniny i větší jemně šupinkovité agregáty chloritu. $V$ proměnlivém množství obsahuje dolomit (xenoblasty do 2 až $3 \mathrm{~mm}$ ) - na složení některých vzorků Tlc-břidlice se dolomit podílí jen nepatrnou měrou ( 1 až $2 \mathrm{obj}$. \%), v jiných však jeho množství dosahuje až kolem 10 obj. \% (tj. rozhraní Tlc-břidlice/krupník). Zejména při vnějším okraji zóny mastkové břidlice se $\mathrm{v}$ hornině objevují jehlice nebo stébla amfibolu. 

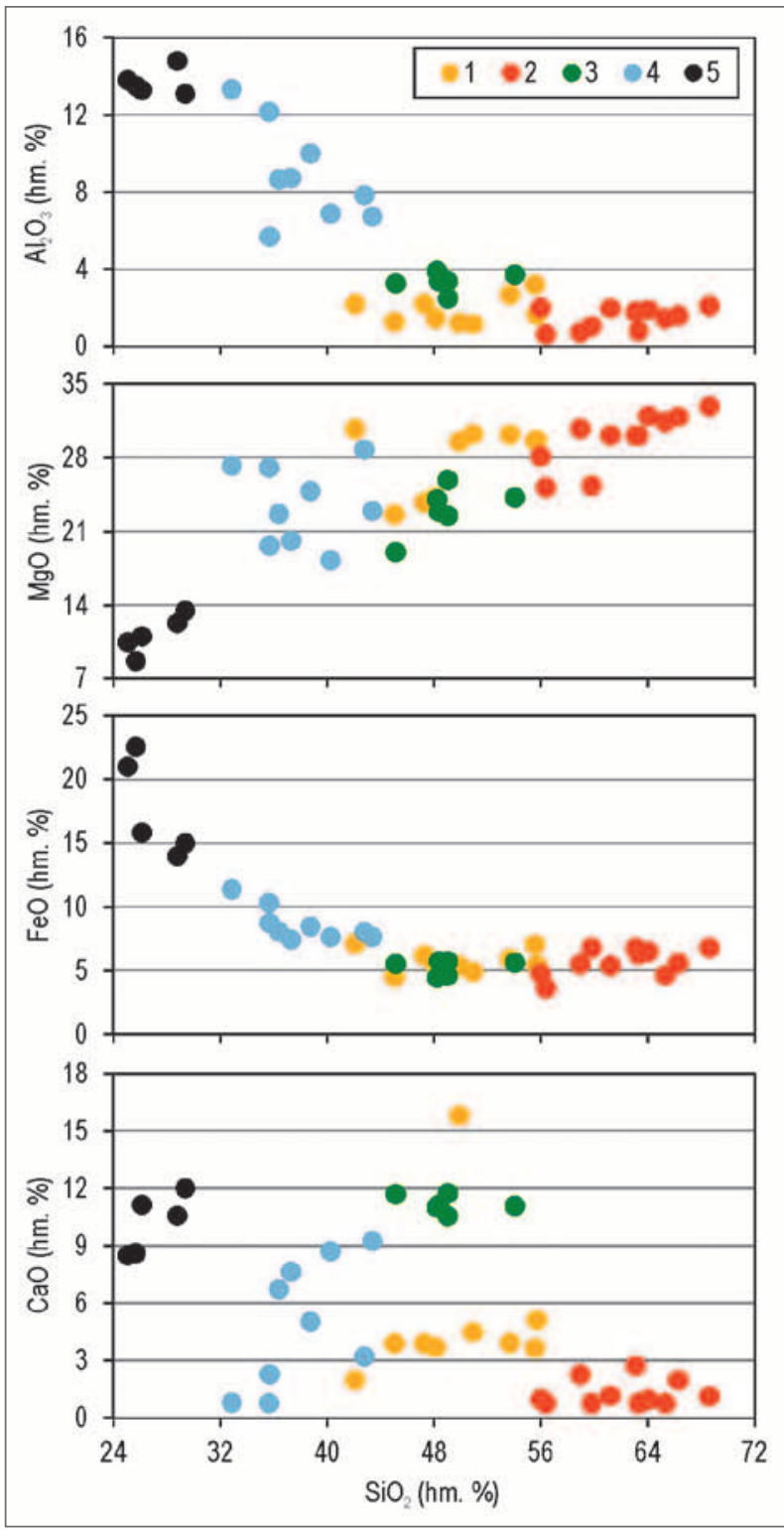

Obr. 3: Harkerův diagram pro horniny krupníkového tělesa a epidot-chloritovou skalinu. 1 - krupník; 2 - mastková břidlice; 3 - tremolitická nebo aktinolitická břidlice; 4 - chloritická břidlice; 5 - epidot-chloritová skalina.

Fig. 3: Harker diagram for rocks of the soapstone body and epidote-chlorite granofels. 1 - soapstone; 2 - talc schist; 3 - tremolite or actinolite schist; 4 - chlorite schist; 5 - epidote -chlorite granofels.

Tremolitická břidlice a tremolitická skalina jsou horniny s převahou Ca-amfibolu, často je amfibol jejich zcela dominantní složkou. Někdy mají plošně paralelní texturu (Tr-břidlice), většinou jsou v nich individua amfibolu uspořádána všesměrně (Tr-skaliny). Tr-břidlice mají šedozelenou až středně zelenou barvu. Skaliny jsou $\mathrm{v}$ průměru tmavší, středně zelené až tmavě zelené, případně až černozelené (jejich amfiboly jsou na rozhraní Tr/Act - viz níže, pro některé horninové partie lze proto použít označení Act-skalina). Amfibol tvoří jehlice nebo stébla, jejichž velikost se v břidlicích pohybuje zpravidla do $10 \mathrm{~mm}$, ve skalinách bývají rozměry individuí výrazně větší, v Act-skalině byly zjištěny dlouze sloupcovité krystaly amfibolu o délce až $8 \mathrm{~cm}$. Omezení amfibolu je

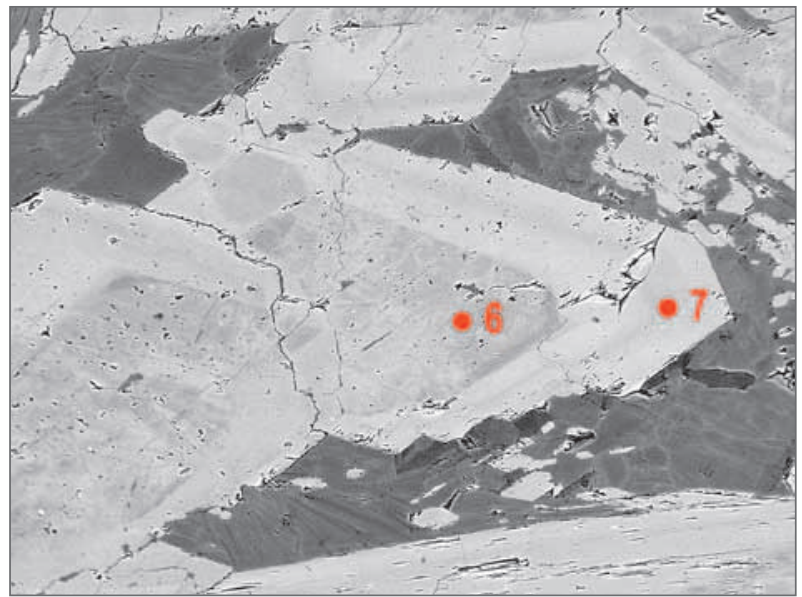

Obr. 4: Zonální amfibol v chlorit-tremolitické břidlici (BSE, šírka snímku $0,8 \mathrm{~mm}$, autor P. Gadas).

Fig. 4: Zoned amphibole in chlorite-tremolite schist (BSE, width of the photo $0.8 \mathrm{~mm}$, author P. Gadas).

převážně hypautomorfní plochami tvarů $\{110\}$ a $\{010\}$. Na složení popisovaných hornin se vždy podílí chlorit v podobě jemně šupinkovitých agregátů mezi jehlicemi či stébly amfibolu (obr. 4), nebo i relativně velkých zprohýbaných šupin, obvykle o velikosti do $20 \mathrm{~mm}$. Některé vzorky obsahují jemně šupinkovitý mastek. V horninách tvořených amfibolem se běžně vyskytují drobné žilky nebo i polohy složené z vláknitého tremolitu šedobílé nebo jemně nazelenalé barvy. $V$ tabulce 1 a na obrázku 3 jsou Tr-břidlice a $\operatorname{Tr}($ Act)-skaliny společně zahrnuty do souboru „tremolitické břidlice“.

Chloritická břidlice je tvořena šupinkami či lupínky tmavě zeleného až černozeleného chloritu o velikosti obvykle do $2 \mathrm{~mm}$, někdy však i přes $10 \mathrm{~mm}$. Ve variabilním množství se na složení horniny podílí amfibol v podobě stébel nebo jehlic. Mezi lupínky chloritu bývají př́itomny drobné agregáty jemně šupinkovitého mastku. Někdy hornina obsahuje porfyroblasty (xenoblasty) dolomitu, zpravidla jen ojedinělé, někdy hojnější ve vzorcích relativně bohatých mastkem.

Ve výbrusech pozorované optické vlastnosti chloritů ve všech horninových typech tvořících krupníkové těleso jsou víceméně shodné: velmi slabý pleochroismus (jemně nažloutlý x jemně nazelenalý) a negativní charakter zóny. Amfibol, jehož chemismus odpovídá tremolitu (viz níže), je ve výbrusech téměř bezbarvý, bez pozorovatelného pleochroismu. Amfibol na přechodu mezi Tr/Act mívá zřetelný pleochroismus ( $\mathrm{X}$ = bezbarvý, $\mathrm{Z}=$ světle nazelenalý). Úhel zhášení Z/c $=15-19^{\circ}$ (pro všechny amfiboly).

Běžnými akcesoriemi hornin krupníkového tělesa jsou apatit a magnetit. Apatit je hojný zejména v horninách bohatých mastkem, $\mathrm{v}$ nichž tvoří hypautomorfní prizmatická individua, ve výbrusech jej lze zastihnout zpravidla $\mathrm{v}$ podobě nepravidelných izometrických průřezů. Magnetit se vyskytuje v podobě drobných zrn (xenomorfní až automorfní průřezy), jen místy se v krupníku nebo Chl-břidlici vyskytují už makroskopicky velmi nápadné oktaedry o velikosti do $4-5 \mathrm{~mm}$. V Tlc-břidlici byly zjištěny xenoblasty dolomitu s hojnými uzavřeninami drobných zrníček magnetitu. K nehojným akcesoriím 


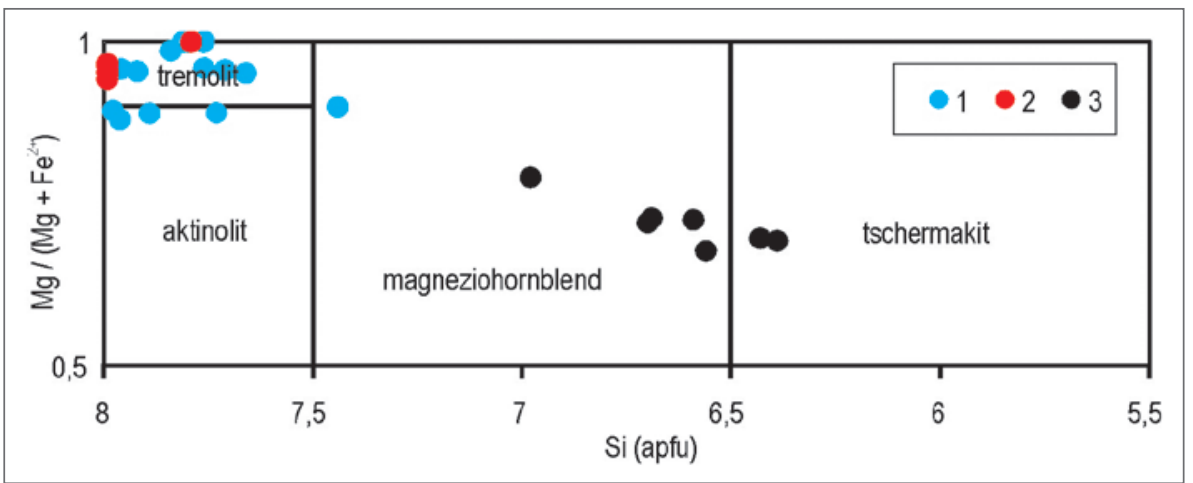

Obr. 5: Amfiboly v klasifikačním diagramu podle Leakeho (1978). 1 - horniny krupníkového tělesa; 2 - amfibolový azbest na puklinách; 3 - epidot-chloritová skalina.

Fig. 5: Amphiboles in classification diagram by Leake (1978). 1 - rocks of soapstone body; 2 - fissure asbestiform amphibole; 3 - epidote-chlorite granofels.

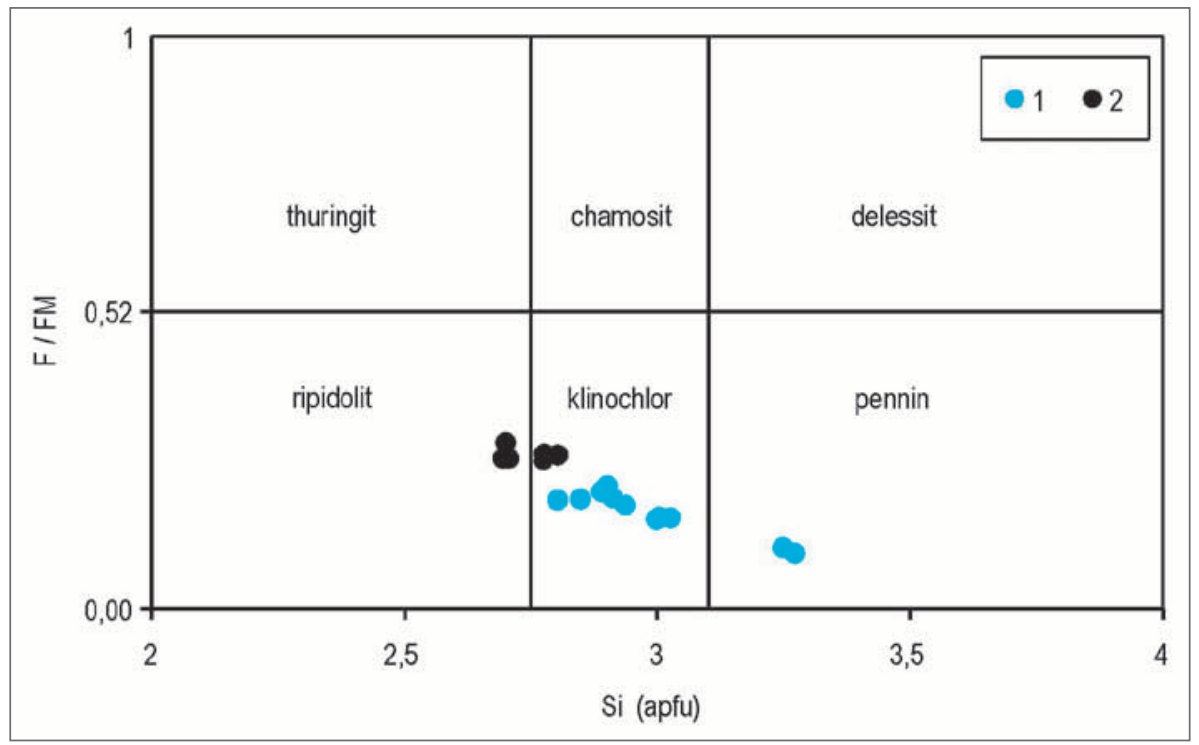

Obr. 6: Chlority v klasifikačním diagramu podle Melky (1965). 1 - horniny krupníkového tělesa; 2 - epidot-chloritová skalina.

Fig. 6: Chlorites in classification diagram by Melka (1965). 1 - rocks of soapstone body; 2 - epidote-chlorite granofels.

patří rutil, ilmenit, zirkon a v tremolitové až aktinolitové skalině blíže neidentifikované sulfidy Fe a Ni.

\section{Chemismus vybraných minerálů hornin krupníkového tělesa}

V tabulce 2 jsou uvedeny výsledky reprezentativních WDX analýz všech tř́ hlavních silikátů v horninách krupníkového tělesa. Složení amfibolu odpovídá převážně tremolitu nebo amfibolu na rozhraní klasifikačních polí tremolitu a aktinolitu (obr. 5). Ve zpětně odražených elektronech lze často pozorovat výraznou chemickou zonálnost krystalů amfibolu (viz obr. 4), v němž světlejší okrajové zóny mají o něco vy̌šši obsahy Fe než centrální části individuí (čísla uvedená u analyzovaných bodů odpovídají číslům analýz v tabulce 2 ). Chemickou zonálnost tohoto charakteru lze považovat za typickou pro amfiboly hornin krupníkového tělesa, $i$ když byla zjištěna i individua amfibolu, v jejichž centru je více Fe ve srovnání s okrajem (v tabulce 2 vyjadřuje analýza č. 1 složení centra, analýza č. 2 okraje téhož krystalu). Složení amfibolového azbestu odpovídá tremolitu $s$ jen nepatrným podílem feroaktinolitové složky (obr. 5).

Chemické složení chloritů odpovídá členům klinochlor-chamositové řady, vždy s výraznou převahou klinochlorové složky. Podle klasifikace Wiewióry a Weisse (1990) jde o klinochlor; podle Melkovy klasifikace (Melka 1965) o klinochlor, méně často pennin (obr. 6). Obsahy $\mathrm{Mn}, \mathrm{Ni}$ a $\mathrm{Cr}$ v analyzovaných chloritech jsou jen relativně nízké: 0,09 až $0,13 \mathrm{hm} . \% \mathrm{MnO}, 0,19$ až $0,25 \mathrm{hm} . \% \mathrm{NiO}, 0,04$ až $0,45 \mathrm{hm} . \% \mathrm{Cr}_{2} \mathrm{O}_{3}$ (WDX analýzy).

Typickými př́měsemi mastku jsou železo $(2,17$ až 4,60 hm. \% FeO, tj. 0,12 až 0,26 apfu Fe) a nikl (až 0,62 hm. \% NiO, 0,03 apfu Ni).

EDX analýzy dolomitu poskytly prakticky shodné výsledky odpovídající $87 \mathrm{~mol}$. \% dolomitové složky, 11 mol. \% ankeritové složky a 2 mol. \% kutnohoritové složky.

Magnetit obsahuje značnou příměs chro$\mathrm{mu}$, zpravidla $\mathrm{v}$ rozpětí 3 až $10 \mathrm{hm} . \% \mathrm{Cr}_{2} \mathrm{O}_{3}$ (WDX a EDX analýzy). V Tlc-břidlici byl v BSE obrazu rozlišen nehomogenní magnetit s centrální ćástí ostře oddělenou od okrajových zón: EDX analýzou bylo při okraji stanoveno $9,69 \mathrm{hm}$. $\% \mathrm{Cr}_{2} \mathrm{O}_{3}$ (tj. 0,30 apfu Cr), v centru 21,95 hm. \% $\mathrm{Cr}_{2} \mathrm{O}_{3}(0,66 \mathrm{apfu} \mathrm{Cr}$ ).

\section{Mineralogicko-petrografická charakteristika epidot- chloritové skaliny}

Jako epidot-chloritová skalina (dále jen ECHS) je označována makroskopicky masivní hornina vyskytující se v lemu krupníkového tělesa, není však jeho součástí. ECHS byla zjištěna pouze při východním okraji krupníkové čočky mezi Chl-břidlicí a amfibolitem. Pravá mocnost ECHS zde dosahuje minimálně 2 až $3 \mathrm{~m}$. Kontakt mezi Chl-břidlicí a ECHS je poměrně ostrý (mocnost přechodné zóny je max. několik cm). Vztah mezi ECHS a amfibolitem lze hodnotil jen na základě horninových úlomků ve svahovinách: patrně jde o plynulý přechod mezi oběma horninovými typy. Studované vzorky ECHS byly odebrány z výchozu na východním okraji spodní etáže a též $\mathrm{z}$ horninových blokủ $\mathrm{v}$ této části lomu (místa odběru při pravém okraji na obrázku 2). 
ECHS je zelenočerná, někdy barevně víceméně jednolitá, jindy s drobnými světlejšími skvrnami s vysokým podílem epidotu. Mikroskopické studium ukazuje, že v partiích s hojným amfibolem je zcela evidentní přednostní orientace jeho prizmatických individuí. Strukturu horniny lze označit nejčastěji jako lepidogranoblastickou.

Na modálním složení ECHS se podílí čtyři hlavní složky: chlorit, epidot, amfibol a opakní minerály (obr. 7 a 8). Hornina je výrazně heterogenní rozložením součástí. V celém souboru odebraných vzorků mírně převažuje chlorit nad epidotem, a proto byl zvolen název ECHS. Vždy je v ECHS prrítomen amfibol, často jako podstatná složka. Všechny studované vzorky mají vysoký obsah opakních minerálů (15 až 25 obj. \%).

Chlorit je v ECHS přítomen v podobě drobných šupinek o velikosti zpravidla do $0,5 \mathrm{~mm}$, často uspořádaných do vějířovitých agregátů. Je slabě pleochroický (téměř bezbarvý x bledě zelený), má negativní charakter zóny. Reprezentativní WDX analýzy chloritu jsou uvedeny v tabulce 3. Podle klasifikace Wiewióry a Weisse (1990) jde o klinochlor, v klasifikaci Melky (1965) analyzované chlority odpovídají ripidolitu nebo klinochloru (obr. 6).

Epidot může v hornině mírně převažovat nad chloritem, v již výše zmíněných světlejších skvrnách dosahuje podíl epidotu kolem 40 až 50 obj. \%. Individua epidotu jsou obvykle prizmatická, ve výbrusech převažují hypautomorfní až xenomorfní průřezy. Epidot je pleochroický (téměř bezbarvý $\times$ bledě žlutý). Obsah železa odpovídá $\mathrm{Ps}_{26-30}$, výsledek reprezentativní WDX analýzy je uveden v tabulce 3 .

Amfibol tvoří hypautomorfní prizmatická individua o délce do $1 \mathrm{~mm}$. Má silný pleochroismus (X = jemně nazelenalý, $\mathrm{Z}=$ modravě zelený - viz obrázek 7) a ve srovnání $\mathrm{s}$ amfibolem hornin krupníkového tělesa o něco větší úhel zhášení $\mathrm{Z} / \mathrm{c}$ (kolem $20^{\circ}$ ). Na základě chemismu (tab. 3) lze amfibol ECHS klasifikovat jako magneziohornblend nebo tschermakit (obr. 5).

Opakní složka ECHS je tvořena Fe-oxidy (hematit, magnetit, pravděpodobně i maghemit) a méně hojným ilmenitem. Ve výbrusech z některých vzorků ECHS lze pozorovat hypautomorfní až automorfní průřezy oktaedrickým krystaly magnetitu o velikosti až $0,2 \mathrm{~mm}$ (obr. 7). $\mathrm{V}$ odraženém světle je zřejmé, že magnetit je přeměněn na $\mathrm{Fe}_{2} \mathrm{O}_{3}$. Jen někdy jde o typickou martitizaci, častěji tato přeměna připomíná spíše maghemitizaci (způsobem šíření i barevným odstínem). V mnoha případech je transformace magnetitu na $\mathrm{Fe}_{2} \mathrm{O}_{3}$ totální. Kromě hematitu vytvořeného martitizací je $\mathrm{v}$ ECHS přítomen i prokazatelně primární hematit v podobě xenomorfních zrn, často velmi nepravidelných tvarů, s výraznými dvojčatnými lamelami. V opakní složce některých vzorků ECHS převažují xenomorfní zrna (nebo spíše nepravidelné agregáty) s četnými výběžky, jejichž identifikace je nemožná, prokazatelně však jde o Fe-oxidy. Na Fe-oxidech různé morfologie byly provedeny WDX analýzy s velmi podobnými výsledky. Kromě dominantního Fe bylo v analyzovaných bodech stanoveno 0,05 až $0,12 \mathrm{hm}$. \% $\mathrm{TiO}_{2}$ a 0,23 až $0,39 \mathrm{hm}$. \% $\mathrm{V}_{2} \mathrm{O}_{3}$. Sumy analýz někdy ukazují na hematit, jindy spíše na magnetit. Ilmenit v ECHS tvoří nepravidelná zrna,

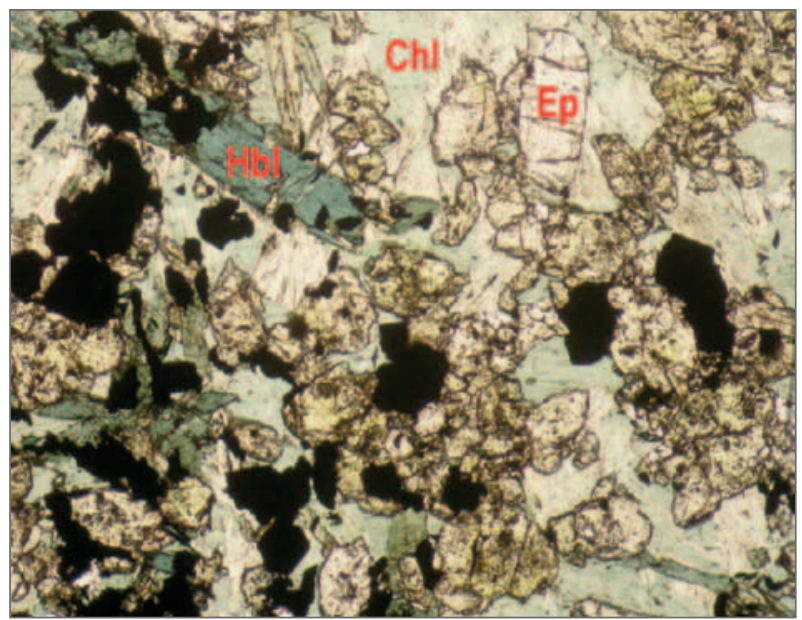

Obr. 7: Epidot, chlorit, amfibol a opakní minerály (hematit a magnetit) v epidot-chloritové skalině. Výbrus v polarizovaném světle, bez analyzátoru. Šírka snímku je 2,2 mm. Autor Z. Juránková.

Fig. 7: Epidote, chlorite, amphibole and opaque minerals (hematite and magnetite) in epidote-chlorite granofels. Thin section in plane-polarized light, without analyzing polarizer. Field of view is $2.2 \mathrm{~mm}$ wide. Author Z. Juránková.

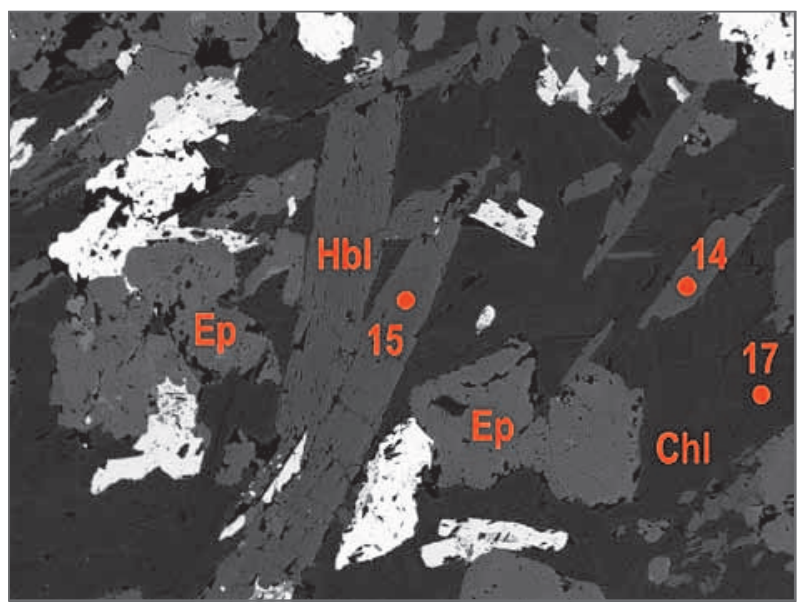

Obr. 8: Amfibol, chlorit, epidot a zrna hematitu nebo magnetitu (bílá) v epidot-chloritové skalině (BSE, šířka snímku $0,9 \mathrm{~mm}$, autor P. Gadas).

Fig. 8: Amphibole, chlorite, epidote and hematite or magnetite grains (white) in epidote-chlorite granofels (BSE, width of the photo $0.9 \mathrm{~mm}$, author P. Gadas).

často postižená leukoxenizací. Někdy je ilmenit lemován titanitem. Analyzovaný ilmenit obsahuje příměs 1,07 až 1,28 hm. \% MnO, což odpovídá 2 až $3 \%$ pyrofanitové složky. Relativně vysoký obsah Fe a Ti v ECHS je zřejmý $\mathrm{z}$ výsledků XRF analýz v tabulce 1 .

V akcesorickém množství byl v ECHS zjištěn titanit, apatit, $\mathrm{TiO}_{2}$-minerál (na základě morfologie pravděpodobně rutil) a flogopit. Titanit tvoří drobná xenomorfní zrna a již zmíněné lemy kolem ilmenitu. WDX analýzami byla v titanitu vedle jeho hlavních složek zjištěna přítomnost 1,01 až $1,11 \mathrm{hm}$. $\% \mathrm{Al}_{2} \mathrm{O}_{3}$ a 0,79 až $0,93 \mathrm{hm}$. \% FeO. $\mathrm{V}$ apatitu bylo stanoveno $2,41 \mathrm{hm}$. \% F a $0,02 \mathrm{hm}$. \% Cl, jde tedy o fluorapatit.

Výsledky XRF analýz ECHS jsou sumarizovány v tabulce 1 a byly začleněny i do obrázku 3. Laboratorní 
gamaspektrometrií byly v ECHS stanoveny relativně vysoké obsahy uranu a thoria: 1,8 až 4,1 ppm U, 2,2 až 4,4 ppm Th (4 vzorky). Nutno poznamenat, že ve všech 27 analyzovaných vzorcích hornin krupníkového tělesa nedosahují obsahy obou prvků 1,5 ppm (mez detekce), ve všech 13 analyzovaných vzorcích amfibolitů $\mathrm{z}$ bezprostředního okolí krupníkového tělesa jsou obsahy U a Th pod 1,5 ppm, s výjimkou jediného vzorku, v němž bylo stanoveno 3,1 ppm U.

\section{Diskuze}

1. Zastoupením jednotlivých horninových typů se krupníkové těleso na Zadním Hutisku neliší od krupníkových těles na lokalitách Smrčina, Bischofsgraben a Medvědí důl, která byla studována shodnými metodami (Zimák et al. 2017; Zimák a Juránková 2018 a dosud nepublikovaná data). V př́padě lokalit Zadní Hutisko, Smrčina a Bischofsgraben lze konstatovat nejen v hlavních rysech identickou zonální stavbu těles, ale i víceméně shodnou povahu hornin $\mathrm{v}$ jejich bezprostředním okolí, které je tvořeno amfibolity, př́p. zelenými břidlicemi vznikajícími jejich retrográdní přeměnou. Je možné, že migrace fluid v průběhu retrográdní fáze variské metamorfózy umožnila vznik symetricky zonálních krupníkových těles typu Zadní Hutisko přeměnou peridotitů, resp. serpentinitů (viz bod 2). Krupníkové těleso v Medvědím dole nemá symetricky zonální stavbu, je situováno v metahornblenditu, jehož hydrotermální alterací se vytvořilo (Hanžl 1995; Zimák et al. 2017).

2. Lze předpokládat, že koncentricky zonální krupníková tělesa sobotínského masivu mají obdobnou genezi. Vznik mnoha výskytů mastkových břidlic a krupníků je vysvětlován přeměnou ultramafitů oceánské kůry, často v podobě ofiolitů začleněných do kontinentálních struktur. Protolitem jsou v tomto případě peridotity, které byly postiženy serpentinizací, po níž následovala steatitizace (jde o Si-metasomatózu). Př́ítomnost $\mathrm{CO}_{2} \mathrm{v}$ roztocích vyvolávajících steatitizaci vedla ke vzniku magnezitu, a tedy k vytvoření biminerálního krupníku s asociací mastek+magnezit. Podrobné informace o těchto procesech uvádí např. Donaldson (1981), Winter (2001), Dill (2010), Bucher, Grapes (2011), Ali-Bik et al. (2012) a Harvey et al. (2014). Na styku peridotitů nebo serpentinitů s horninami bohatými křemenem (např. pelity, resp. metapelity) může během metamorfózy dojít ke vzniku reakčních zón. Vytvoří se tak těleso s výraznou koncentrickou zonálností. $\mathrm{V}$ nejjednodušších prrípadech je serpentinizovaný ultramafit $\mathrm{v}$ centru lemován zónou mastku, na okraji tělesa dominuje chlorit nebo biotit (v závislosti na podmínkách metamorfózy). Mezi zónou mastku a vnější zónou chloritu nebo biotitu může být vyvinuta zóna aktinolitu. Někdy serpentinit není př́tomen, jádro těchto těles je tvořeno krupníkem, pak následuje zóna aktinolitu a okrajová zóna chloritu nebo biotitu.
Lze předpokládat, že protolitem krupníkových těles sobotínského masivu jsou ultramafity: hornblendity nebo peridotity (resp. serpentinity). Již Kretschmer (1911) považuje krupníková tělesa sobotínského masivu za výsledek alterace ultramafitů charakteru websteritu nebo hornblenditu. Podle Fialy et al. (1980) jsou serpentinity a krupníková tělesa produktem přeměny peridotitů. Jelínek a Souček (1981) považují jednotlivé zóny krupníkových těles za reakčně-metasomatické zóny, vzniklé na úkor serpentinitu na styku dvou chemicky odlišných prostředí, a dodávají, že zonálnost těles je shodná bez ohledu na to, zda je okolní horninou rula či amfibolit. Hornblendity (metahornblendity) jsou v prostoru sobotínského masivu poměrně hojné, jejich steatitizace byla doložena na lokalitě Medvědí důl (Hanžl 1995; Zimák et al. 2017).

Serpentinity jsou v sobotínském masivu zcela ojedinělé, $\mathrm{v}$ tělese serpentinitu na Rudné hoře byly zjištěny steatitizované partie (Fiala et al. 1980, Zimák 1999). Serpentinit byl nalezen i v haldovém materiálu na lokalitě Smrčina (dosud nepublikováno). Peridotity a jejich hydratací vzniklé serpentinity mají obecně velmi nízké obsahy vápníku. To platí i pro serpentinity sobotínského masivu (0,50 a 0,56 hm. \% CaO uvádí Fiala et al. 1980 a Zimák 1999). Přeměna serpentinitu na krupníkové těleso typu Zadní Hutisko proto vyžaduje významný přínos vápníku. Jeho zdrojem mohl být okolní amfibolit, jenž je v kontaktní zóně s krupníkovým tělesem přeměněn na epidot-chloritovou skalinu. Př́nos vápníku v průběhu steatitizace se projevil i vznikem dolomitu místo obvyklého magnezitu (magnezit je typickým minerálem krupníků vznikajících přeměnou ultramafitů obklopených metapelity).

\section{Závěr}

Krupníkové těleso na lokalitě Zadní Hutisko v sobotínském masivu má symetricky zonální stavbu. Od centra k okraji tělesa lze rozlišit čtyři hlavní typy hornin: (1) krupník (mastek + dolomit), (2) mastková břidlice, (3) tremolitická břidlice nebo skalina (Ca-amfibol je zastoupen hlavně tremolitem, $v$ některých partiích amfibolem na rozhraní tremolit/aktinolit), (4) chloritická břidlice (dominuje klinochlor). Běžnými akcesoriemi hornin krupníkového tělesa jsou magnetit (často s vysokým obsahem chromu) a apatit. Krupníkové těleso vzniklo pravděpodobně metasomatickou přeměnou serpentinitu (serpentinizovaného peridotitu) na styku s amfibolitem. Amfibolit je v kontaktní zóně přeměněn na epidot-chloritovou skalinu s variabilním podílem amfibolu (magneziohornblend nebo tschermakit), vždy se značným obsahem rudních minerálů (magnetit, hematit a také ilmenit) a také s relativně vysokými obsahy U a Th ve srovnání s okolními amfibolity, horninami krupníkového tělesa i ultramafity sobotínského masivu. 
Literatura

Ali-Bik, M. W., Taman, Z., El Kalioubi, B., Abdel Wahab, W. (2012). Serpentinite-hosted talc-magnesite deposits of Wadi Barramiya area, Eastern Desert, Egypt: Characteristics, petrogenesis and evolution. - Journal of African Earth Sciences, 64, 77-89. https://doi.org/10.1016/j.jafrearsci.2011.11.002

Bucher, K., Grapes, R. (2011). Petrogenesis of metamorphic rocks. - Springer Verlag Heidelberg etc.

Burkart, E. (1953). Mährens Minerale und ihre Literatur. Nakladatelství ČSAV, Praha.

Dill, H. G. (2010). The "chessboard" classification scheme of mineral deposits: Mineralogy and geology from aluminum to zirkonium. - Earth-Science Reviews, 100, 1-420. https://doi.org/10.1016/j.earscirev.2009.10.011

Donaldson, M. J. (1981). Redistribution of ore elements during serpentinization and talc-carbonate alteration of some Archean dunites, Western Australia. - Economic Geology, 76, 1698-1713. https://doi.org/10.2113/gsecongeo.76.6.1698

Fiala, J., Jelínek, E., Pouba, Z., Poubová, M., Souček, J. (1980). The geochemistry of the ultrabasic rocks of the Sobotín amphibolite massif (Czechoslovakia). - Neues Jahrbuch für Mineralogie - Abhandlungen, 137, 257-281.

Gába, Z. (1989). Hmotné doklady o použití krupníku na severní Moravě. - Severní Morava, 58, 39-51.

Hanžl, P. (1995). Hornblendit ze šupiny sobotínského masívu jihovýchodně od Zámčiska. - Geologické výzkumy na Moravě a ve Slezsku v roce 1994, 84.

Harvey, J., Savov, I. P., Agostini, S., Cliff, R. A., Walshaw, R. (2014). Si-metasomatism in serpentinized peridotite: The effects of talc-alteration on strontium and boron isotopes in abyssal serpentinites from Hole 1268a, ODP Leg 209. - Geochimica et Cosmochimica Acta, 126, 30-48. https://doi.org/10.1016/j.gca.2013.10.035

Jelínek, E., Souček, J. (1981). Geochemie jesenického a sobotínského amfibolitového masivu. - Acta Universitatis Carolinea, Geologica, 1981, 379-411.

Košuličová, M., Štípská, P. (2007). Variations in the transient prograde geothermal gradient from chloritoid-staurolite equilibria: a case study from the Barrovian and Buchan-type domains in the Bohemian Massif. - Journal of metamorphic Geology, 25, 19-35.

Koverdynský, B. (1993). Geologické problémy silezika. - In: Přichystal, A., Obstová, V., Suk, M. (eds): Geologie Moravy a Slezska, 31-40, Moravské zemské muzeum a Sekce geologických věd PřF MU Brno.

Kretschmer, F. (1911). Das metamorphe Diorit- und Gabbromassiv in der Umgebung von Zöptau (Mähren). - Jahrbuch der kaiserlich-königlichen Geologischen Reichsanstalt, 61, 53-180.

Kruta, T., Paděra, K., Pouba, Z., Sládek, R. (1967). Die Mineralienparagenese in dem mittleren Teile des Altvatergebirges (Hrubý Jeseník, Hohes Gesenke, ČSSR)I. - Časopis Moravského muzea, Vědy přírodní, 52, 5-28.

Leake, B. E. (1978). Nomenclature of amphiboles. - American Mineralogist, 63, 1023-1052.

Melka, K. (1965). Návrh na klasifikaci chloritových minerálů. - Věstník Ústředního ústavu geologického, 40, $23-27$.

Nepejchal, M. (2000). Výskyt krupníku v Sobotíně a Vernířovicích. - Minerál, 8, 4, 313-314.

Novotný, P. (1998). Krystalovaný mastek ze Zadního Hutiska u Vernírovic. - Minerál, 6, 6, 433.

Novotný, P. (2003). Současný stav některých mineralogických lokalit u Sobotína. Výsledky programového projektu Ministerstva kultury ČR v letech 1997-1998. - Zprávy Vlastivědného muzea v Olomouci, 279, 20-55.

Opletal, M., Koverdynský, B., Holásek, O., Růžička, M. (1996). Geologická mapa ČR. List 14-42 Rýmařov. - Český geologický ústav, Praha.

Opletal, M., Sekyra, J., Novák, M. (1997). Geologická mapa ČR. List 14-24 Bělá pod Pradědem. - Český geologický ústav, Praha.

Pouba, Z. (1969). The Sobotín basic complex and its metallogenesis. - Acta Universitatis Carolinea, Geologica, 1969, $105-117$.

Pouba, Z. (1971). Acid rocks at the contacts of basic and ultrabasic intrusions with biotite gneisses (Vysoký Jeseník Mts., Czechoslovakia). - Acta Universitatis Carolinea, Geologica, Hejtman Vol., 1971, 123-139.

Pouba, Z., Dvořák, J., Mísař, Z., Musilová, L., Prosová, M., Röhlich, P., Skácel, J., Unzeitig, M. (1962). Vysvětlivky k přehledné geologické mapě ČSSR 1 : 200000 M-33-XVIII Jeseník. Ústřední ústav geologický, Praha.

Přichystal, A., Novotný, P. (1999). Geochemické studium metabazitů ze střední části sobotínského amfibolitového masivu (silezikum). - Geologické výzkumy na Moravě a ve Slezsku v roce 1998, 121-125.

Schulmann, K., Oliot E., Košuličová, M., Montigny, R., Štípská, P. (2014). Variscan thermal overprints exemplified by U-Th-Pb monazite and K-Ar muscovite and biotite dating at the eastern margin of the Bohemian Massif (East Sudetes, Czech Republic). - Journal of Geosciences, 59, 389-413.

Souček, J. (1981). Geochemie devonských metabazitů Hrubého a Nízkého Jeseníku. - Časopis pro mineralogii a geologii, 26, 2, $125-142$.

Šafář, J. et al. (2003). Olomoucko. - In: Mackovčin, P. - Sedláček, M. (eds): Chráněná území ČR, svazek VI. Agentura ochrany př́rody a krajiny ČR a EkoCentrum Brno, Praha.

Wiewióra, A., Weiss, Z. (1990). Crystallochemical classifications of phyllosilicates based on the unified systems of projection of chemical composition: II. The chlorite group. - Clay Minerals, 25, 83-92. https://doi.org/10.1180/claymin.1990.025.1.09

Winter, J. D. (2001). An introduction to igneous and metamorphic petrology. - Prentice-Hall Inc. Upper Saddle River, New Jersey.

Zimák, J. (1999). Serpentinity sobotínského amfibolitového masivu. - Geologické výzkumy na Moravě a ve Slezsku v roce 1998, 129-131.

Zimák, J., Dalajková, K., Donocik, R., Krist, P., Reif, D., Štelcl, J., Kopecká, L. (2016). Využitelnost terénních rentgenfluorescenčních analyzátorů ke stanovení chemismu cementářských surovin - na př́kladu velkolomu Mokrá. - Zprávy o geologických výzkumech, 49, 79-82.

Zimák, J., Fojt, B., Juránková, Z. (2017). Mineralogie krupníkového tělesa v Medvědím dole u Koutů nad Desnou v Jeseníkách. Geologické výzkumy na Moravě a ve Slezsku, 24, 97-102. 
Zimák, J., Juránková, Z. (2018). Petrografie a mineralogie krupníkového tělesa na lokalitě Bischofsgraben u Sobotína (Hrubý Jeseník). - Acta Musei Moraviae, Sci. geol., 103, 1, 3-16.

Zimák, J., Novotný, P. (2002). Lokalita č. 15. Vernířovice - Zadní Hutisko. In: Zimák, J. - Novotný, P., Fojt, B., Novák, M., Vávra, V., Kopa, D., Losos, Z., Prinzová, E., Skácel, J.: Exkurzní průvodce po mineralogických lokalitách na Sobotínsku, 57-60. UP Olomouc. 